\title{
Ethnography Study in Malang, Indonesia: Petekan Tradition in Tengger Community
}

\author{
Rendra Kresna ${ }^{1}$, Agus Sholahuddin ${ }^{1} \&$ Kridawati Sadhana ${ }^{1}$ \\ ${ }^{1}$ Faculty of Social and Political Sciences, University of Merdeka, Malang, East Java, Indonesia \\ Correspondence: Agus Sholahuddin, Faculty of Social and Political Sciences, University of Merdeka, Malang, \\ East Java, Indonesia.
}

Received: June 23, 2015 Accepted: July 22, 2015 Online Published: November 13, 2015

doi:10.5539/res.v7n12p153 URL: http://dx.doi.org/10.5539/res.v7n12p153

\begin{abstract}
This research is discussing about a tradition in Tengger community, Indonesia. The tradition is named as Petekan which means pressing or pushing lower abdomen in order to know whether a woman who is in fertile period is pregnant or not. The tradition was conducted because of the belief that if there is a pregnant woman without married (doing free sex), the local people will be suffered by disaster or infected disease (pageblug) that is difficult to be healed. In this study, we used descriptive study by ethnographic qualitative approach. We found that Petekan ceremony has been conducted since long time ago and preserve until today. The community conducts the tradition once in three months. Almost every year, by conducting the tradition, they found a pregnant woman without marriage. The implementation of the Petekan involves all village members which shows how important if this activity for the people. Sanction for violation in the tradition is applied both for male and female.
\end{abstract}

Keywords: Petekan, marriage, tradition, culture, community

\section{Introduction}

A tradition of a community cannot be separated from values, system, norm, social behavior, social relationship, and social control. One of the well developed traditions at Tengger community is Petekan. It is an activity to press lower abdomen of a woman who is in fertile period in order to know whether she is pregnant or not. The tradition has been practiced since long time ago. In the beginning, it was conducted because of a belief that if there is a pregnant woman without marriage, the community will be suffered of disaster or infected disease (pageblug) which is difficult to be healed. Thus, tribal chief (shaman) along with the village leader (pamong praja) have initiative to conduct a preventive action for the social distortion, by doing Petekan for once in three months.

The Petekan tradition is very old one so that is difficult to track when it was conducted for the first time. It is believed that this tradition only exist in village Ngadas. The Petekan tradition has two sides, both for virginity and for pregnancy test for virgin woman and widow. This activity involves all of people in the village. The continuity of this tradition needs to be kept because it is proven that it has many social functions such as to unite people in the community. With this function, many development activities can be conducted very well. This tradition is a form of local wisdom that needs to be kept. For young generation of Tengger community, they should hold the people culture tradition and it is conducted by preserving many cultural arts and traditions since currently, there are many religions have entered and influenced the Tengger community.

The objectives of this research as follow: (1) to analyze Petekan tradition in Tengger community in village Ngadas, sub-district Poncokusumo, district, Malang, East Java, Indonesia, (2) to analyze what kind of value that is found in the community, and (3) to analyze social sanction or custom sanction which be conducted as social control.

\section{Literature Reviews}

Culture is the whole complex of things that created history and continued from time to time through traditions that involve social organization, economic, religion, belief, habit, law, art, technique, and science (Tylor, 1871). Therefore, culture was created through passed time history process that developed from generation to generation. It is a complex thing which contain of science, knowledge, belief, art, morality, laws, custom, and other habit which is obtained by people as member of a community. Culture consists of explicit and implicit attitude patterns that obtained and delivered through symbols. It consists of ideas with tradition pattern (that appear and selected 
from history process) especially for related values that have super-organic (Kroeber \& Kluckhon, 1952).

As the whole of human way of life, culture includes the results of group living with material and immaterial pattern. Material culture or artifact is all of human's creation that formed as particular objects such as tools, buildings, weapons, and vehicles. With regard to the material culture, Deetz (1977) defined it is as the dimension of the physical world that is shaped "according to culturally dictated plans," sweeping up a vast range of products of human behavior and arguing that material culture studies needed to become a central dimension of all anthropological scholarship and perhaps any social science. Meanwhile, immaterial culture or mentifact is something abstract that created by human such as belief, custom, laws, etc (Malinowski, 1944).

Culture is stated as the whole human way of life that conducted by all people which involves the way of acting, behaving, and thinking and also any result of all activities and creation of material or spiritual, civilization, and the advance of the intelligence. Culture is the whole complex of things that consist of knowledge, belief, art, manner, rule, custom, and any efforts and attitudes that owned by individu who becomes society member. Culture is formed as a set of symbols that owned and run by all society members. According to Horton and Hunt (1980), culture is a system of norms that covers folkways mean customary or habitual ways a group does certain things or mores which is powerful ideas of right and wrong which grant legitimacy to certain behaviors and actions and forbid others. Horton and Hunt (1980) also mentioned that the value is directing someone's behavior and consideration, but not to judge whether the particular behavior is right or wrong. Value is one important part of a culture. If an action is stated as legal means morally it can be accepted if it runs harmonically with the established values and supported by people where the action is conducted. Meanwhile, recent article regarding culture was conducted by Lamont et al. (2015). They highlighted two types of cultural processes: identification and rationalization. The also illustrated and described four processes to be significant analytical exemplars of these two types of cultural processes, which are racialization and stigmatization (for identification) and standardization and evaluation (for rationalization).

Social value as general guidance that has been existed for long time ago, that directs the attitude and satisfaction in the daily living. To determine that something stated as good or bad, appropriate or inappropriate, it have to pass a consideration process. Suparto states that social values have general function in the society such as it can contribute a tool set to direct people in thinking and behaving. Besides that, social value also functioned as final determinant for human to fulfill social roles. Social value can motivate someone to create the expectation that is appropriate with their role. According to Wood and Leighton (2010), social value refers to wider non-financial impacts of programmes, organisations and interventions, including the wellbeing of individuals and communities, social capital and the environment. Meanwhile, Young (1942) stated that social value is abstract assumption that mostly unrealized about what is considered as important thing in society. Whereas Green (1972) stated that social value is an awareness that is relatively accompanied by emotion to the object. In other theory, Doyle (1981) stated that that value is the description about what is wanted, appropriate, and can influence social behavior of the valued people. The value also can be defined as an idea or concept about what is considered as important thing for someone in their life (Fraenkel, 1977). Besides that, the truth of a value does not demand the existence of empirical proof, but it is more related to the appreciation and what is desired or undesired, liked or unlike by someone. Meanwhile Schwartz and Bilsky $(1987,1990)$ discussed five features of the values construct are recurrently mentioned in the values literature, which are beliefs, desirable end states or behaviors, trans-situational guides, selection and evaluation of behavior and events, and the relative ordering of beliefs, desirable end states or behavior, or guides. Then, Allport (1961) mentioned that value is a belief upon which a man acts by preference. It is a cognitive, a motor, and above all, a deeply appropriate disposition". It means that man selects or chooses the activity based on value that they trusted.

Related to social values, social norm is the definition that includes results of various group interaction, both results of interaction of the past and current groups, which include all of social values, customs, traditions, habits, conventions, and others. Social norm is general standards about individual attitude and behavior of group members that is desired by the group. It is about various things that are related to the group living which creates attitude and behavior norms of the group members. Group and social norms will not emerge by itself, but it is created in the social interaction among people in the social group. Social value always occurs along with the existence of human interaction in a group. In other words, social norm is the result of social interaction between members of a group. Therefore, social norm is interaction of a group, and social value is equal to group norm (Sherif, 1935).

Social control is behavior restriction process of members of social system in the established limits by using norm and power. Meanwhile, social capital is more based on general social policies. It is a place for the fusion of belief and the important factors for economic health of a country, based on cultural roots (Fukuyama, 1995). Social capital is collective energy of people (or nation) in order to overcome problems and it is a source of motivation in 
order to reach economic advance for the people or nation (Durkheim, 1973).

\section{Methodologycal Framework}

This research was conducted by ethnographic qualitative approach of Spradley model (Spradley, 1980) by using exploratory research of a case study. We deeply explored phenomena with limited theoretical support to emerge newly approach theory. There are not many research have been conducted about virginity testing in Indonesia. Yin (2003) emphasized that case study is one approach that can be used in social research one of the research strategies which gives quite large chance for the researcher to articulate their experience and knowledge in observing and evaluating phenomena.

Qualitative approach is a research process based on method that investigates a social phenomena and human problems. In this approach, a researcher makes a complex description, examines the words carefully, detailed reports which are from informants, and conduct the study in natural situation (Creswell, 1998). Bogdan and Tylor (1975) stated that qualitative methodology is research procedures that result descriptive data as written or orally words from the observed people and behavior.

For analytical method, in this study we employed ethnography approach. Ethnography research method perceived to be able to dig information deeply with various sources. By using participant observatory technique, the ethnography approach becomes a unique research method since it requires direct researcher participation in particular social community. Ethnography has been used as the supports of qualitative research. Ethnography research is the activity of collecting information and data about the way of life, many social activities and also various cultural objects of society which is conducted systematically. Ethnography model tends to direct to the inductive, constructive, transferability, and subjective pole. Besides that, it also gives more emphasize on idiographic by describing the existence culture and tradition.

Ethnography method which is employed in this research is based on Spradley model (1980). Spradley (1980) stated about the steps to conduct ethnography interview to seek research conclusion with ethnography method. The steps can be done by establishing an informant, conducting ethnography interview, making ethnography notes, submitting descriptive question and conducting ethnography interview analysis, making domain analysis, submitting structural question, making taxonomy analysis, submitting contrast question, making component analysis, finding cultural themes and writing an ethnography. This Spradley thought gives clear historical mapping about ethnography research method besides the description about its steps.

In the ethnography study, we obtained information form informant (respondents) who provided information related to the studied object. The informant who were assigned in this study were: village leader and village secretary (village officer), tribal chief (shaman), shaman assistant (Pak Legen), security officer (Jagabaya), village midwife, and Petekan participants. They were selected based on purposive random sampling.

\section{Empirical Results and Discussion}

\subsection{The Implementation of Petekan Tradition by Tengger Community}

This tradition conducted once in three months. This tradition coordinated by Pak Legen (not people name, but the occupation). Although there is a spiritual leader who is called as Dukun (Shaman) whose name is Mbah Ngatrulin, but Petekan ceremony has become the task and responsibility of Pak Legen to lead and conduct this tradition. According to informants, this ceremony was very old tradition. Many old women in the village who had been interviewed by the researcher said that Petekan has existed since they were teenager. Moreover, there is a granny who said that this tradition has existed since she was a child. The culture in the village Ngadas is a culture as what it was mentioned by Malinowski (1944), that culture is the whole way of human life. Culture includes the results of human life which is patterned as material and immaterial. The Petekan tradition is one of the nonmaterial culture or mentifact,

The Petekan tradition has been started from the past, where many young people did promiscuity which made many pregnancy without marriage. Because of shame, then the new baby born was thrown away. People in the community believed that action created pagebluk in the village, where many children got sick in the morning and died in the evening, or got sick in evening and died in the morning. When there was a girl who is pregnant without marriage, usually there were many unusual things occurred which could be seen by many nature signs, such as rooster crowed before its time. For example, there was a rooster crowed between $8.00 \mathrm{pm}$ until $10.00 \mathrm{pm}$. The other strange phenomena is another women who are not pregnant are also suffering by nyidam (interested on something in the pregnant period). If the phenomena are occurred, even though it is not three months yet from the previous Petekan, people were be afraid of disaster, so that the Petekan tradition would be conducted because of the emergency situation. 
The procession is started when something is found (fetus in uterus) in a woman. Then Dukun Bayi (shaman for babies) tries to get witnesses and asks them about the incident. Then village midwife will check it first. Almost every year, there is a case of Petekan which mean that a woman is found pregnant without marriage. Moreover, sometimes the man who has done this is married man. If there is a pregnant woman without marriage and she is not identified before Petekan is conducted, the signs can be identified such as people (both male and female) in that village have no interest in eating, even for delicious food. Many children suffer fever, and many people in the village are experiencing nyidam, both male and female. Once the woman is found, then the disaster and illness are automatically ended. Another nature signs if there is a woman that pregnant without marriage is most people got headache at the same time. There is also a tiger comes to the village. Sometimes rooster crowed not in the right time.

The Petekan usually starts at $07.00 \mathrm{pm}$ until $09.00 \mathrm{pm}$ if there is no complication. It cannot be conducted in the morning or noon because people are still busy with their works. If it is found a pregnant woman without marriage while conducting the Petekan, then it will be take longer time because there will be a meeting to discuss about the incident. In this case, a custom sanction will be given. A sanction can also be given if there is an adult man visits a lady's house until late night. He will get a sanction in form of cleaning the village road in the morning, from uphill to downhill. It is conducted to prevent the unwanted incident.

The Petekan seems to have power in preventing Tengger's young generation not to do sex without marriage. In Tengger, adult male usually get married at 20 years old, whereas the young girl get married at younger age which is 17 years old. In the Petekan, all teenagers (ladies) and widows in fertile period will become the participants. There are no teenagers or widows who reject to attend this tradition. Everyone, even the ones who feel guilty also follow the procession. Village security will call them or their parents and ask them to go home before Petekan is conducted. They will be awaited or picked up at their place.

The tradition has two functions which are for virginity and the pregnancy test. But, Petekan is not completely practiced as virginity test like in the other countries, such as India or Turkey. The appearance of Petekan is more because of social reason which is the curiosity of pregnancy without marriage.

Virginity test is practiced in many countries. In India, there is century's habit that called as Kukari ki Rasam (yarn ritual), where the yarn reels is used to detect whether a woman's hymen is torm. Unfortunately, virginity testing is not only to make women feel pain, but also as a way for the women and her family to commit extortion to the groom. Bride family could force the man and his family to pay some amount of money once they have proven that their daughter is virgin. Regarding the test, police officer claims that they cannot do anything because it is not forbidden since it is not included in Indian penal code. Therefore it cannot be stated as a crime thus the practice of the virginity test cannot be prosecuted in court

In Turkey, the government has taken actions to muffle the controversy of the virginity test after five girls, in the age of 12-16 years old, tried to suicide after they have been forced to do virginity test after they came late to their hostel Virginity is seen as very important thing in Islamic culture. Virginity test has been occurred in Turkey whose law states that husband is family head. For newly married couple, virginity is very important thing which is symbolized by red band in the wedding day. Some social reasons to conduct this tests are as follows: consensus of sex between underage children, certification that the relationship does not occurred before the divorce, suspicion of sex by unmarried person, consensus between adult about immoral behavior, force to marry due to failed of virginity test, small bleeding after the first sex for married couple, and virginity certification before marriage (Woman Health Information Center, 2004).

In South Africa, there were 120,000 people predicted dead in 2000 as the cause of AIDS disease and there are more than 100,000 orphans because of AIDS. It motivated Africa leaders interested to relieve the old culture tradition of virginity testing as the way to protect themself against AIDS. They believe that by virginity testing, they will protect themself and tell others not do sex without marriage. The test has become very popular and hundreds girls are waiting in the queue for three hours every day to be tested. Many people believe that both male and female children must be introduced with sex education, condom, AIDS, and other sexual infected disease. Leaders in Africa, however, reject to educate about condom because they believe that it will encourage the curiosity of male and female children to try it. There is a report about the increasing number of parent who force their children to participate in the virginity test.

\subsection{The Existence of Values of the Petekan Tradition}

Various cultural sites suggest that the Keo's traditional house is basically having value as a center and controller of all social activities in everyday life. Cultural values of the traditional house also contain value as a protective for the community togetherness in everyday life. It appears from the fact that the traditional house of Keo 
community has become part of their lives. As a protector, Keo's the traditional house of Keo can be divided into two types namely $\mathrm{Sa}^{\prime} o \mathrm{Pu}^{\prime} u$ and $\mathrm{Sa}^{\prime} o$ Yeda. The function of the traditional house from long ago until today, not only a place for shelter, but also as a social entity and as a center for various activities undertaken by Keo community members.

There is value set in this tradition. For the doer who are found guilty will get the sanction where they have to clean the village, such as cleaning the road from the house of the woman who is pregnant to the downhill, and back to the uphill until the village Temple (Pura). In the Petekan process, if it is found a pregnant woman without marriage, then the woman will be arrested for a moment and asked how she becomes pregnant, and who makes her pregnant. If it is known who makes her pregnant then in that day, the man will be called and asked to marry her. They also will get the sanction or punishment of paying 50 sacks of cement and cleaning the road around the village. The aim of this sanction is to give warning to others not to do the same thing. It is clear that the value of the custom sanction is the feeling of shame for male and female adolescents and widows; they are warned not to do free sex. Besides that, it also gives cautious to the doers, not to repeat the bad behavior in the future. So, it can be considered as one of social controls and also social capital.

Although the tradition has been socialized, but there are still many cases. It shows that the socialization is not enough to create social order. Social norms in the community are not strong enough to have self-enforcing in guarantee the social regularity. Therefore, besides the socialization process, people also need to create social control system which has implication to the Petekan tradition, and becomes social capital which is needed in order to create moral community type that cannot be obtained in the case of human capital. The social capital is based on the general social policy which is a place to combine belief and the important factor for economic health of a nation that lean on the cultural roots (Fukuyama, 1995).

As we know, the implementation of this Petekan involves all village members. It shows how urgent this activity for the people as a whole. It also shows that there are other important main values namely togetherness. The value becomes very important in the Tengger community. People in village Ngadas put monogamy values as the important values. Besides that, values of right, responsibility, and duty seem to be very prominent and become the basic of the existence phenomena, especially the impact of the related behavior. In the Petekan implementation, the judging element seems to be very prominent. It cannot be separated from the value that underlines a social norm that is an important part of culture.

\subsection{Custom Sanction in Violating the Petekan}

In the Petekan ceremony, if it is found a woman who is pregnant without marriage, then she will receive custom sanction by paying established fine, doing activity that will emerge shame feeling to the related her or her couple. According to their rule, the sanction is that each of she and he has to give in 50 sacks of cement each. Whereas, when there is a woman who is pregnant with married man, the sanction is by giving in 100 sacks of cement for the man and 50 sacks for woman. This punishment must be obeyed without any denial. There is no difference between rich or poor people, all guilty people must pay the fine. This fine is used to build gutters and small roads or village roads by the community. Usually, the collected fund will be combined with other voluntary fund from the people in the village. Those conditions show how the social control system is needed in the social life. As mentioned above, social control is behavior limitation process of social system members in the established limits by using norms and power. Social control can be in forms of formal or informal, vertical or horizontal. For example, Tengger people in village Ngada, are controlled especially by social values and norms. In fact, although social values and norms have been socialized, there are still the distortion or violation. It shows that socialization is not enough to create social regularity. Therefore, it needs social sanction as the social control. As what is mentioned by Soekanto (2003) that social control is monitored by society to all of social process, both planned and unplanned which will educate, invite, or even force all the people in order to obey the existing rules and social values.

\section{Conclusion and Recommendation}

Petekan ceremony that conducted by people in Ngadas Village is run for once in three months. This tradition coordinated by Pak Legen (not people name, but the occupation). This ceremony was very old tradition, that is difficult to be tracked when it is conducted for the first time. The appearance of Petekan tradition started from the past where many young people had promiscuity, thus it caused them pregnant before marriage. After the phenomenon, there was pagebluk in the village where many children get sick in the morning and died in the evening. Almost every year the case of Petekan where participants are found pregnant without marriage happens.

The activity of Petekan tradition involves all of village people. It shows how urgent this activity for people as a whole. The description of the other important values in the Petekan implementation is related to the monogamy 
and there is no polygamy in village Ngadas. Petekan tradition is based on values and norms which include social implication related to the duty and responsibility of people.

In the Petekan ceremony, if there is violation such as a woman who is pregnant without marriage, she will receive custom sanction by paying established fine or doing activity that will emerge shame feeling to the related person or couple. It is applied both for male and female.

Related to this research, it is expected to continue the tradition because it is proven that it has many social functions that can keep people in unity. With the unity of the community, many development activities can be conducted very well. Those traditions are the form of local wisdom that needs to be kept. For young generation of Tengger people, they should hold the people culture tradition by preserving many cultural arts and traditions. It is expected that the cooperation of all religion figures, besides running their religion principle well but also to give respect in the existence of people culture tradition.

\section{References}

Allport, G. W. (1961). Pattern and Growth in Personality. New York: Holt, Rinehart \& Winston.

Bogdan, R., \& Taylor, S. J. (1975). Introduction to Qualitative Research Methods: A Phenomenological Approach to the Social Sciences, New York: John Wiley.

Creswell, J. W. (1998). Qualitative inquiry and research design: Choosing among five designs. Thousand Oaks, CA: Sage.

Deetz, J. (1977). Material culture and archaeology_What's the difference. In L. Ferguson (Ed.), Historical Archaeology and the Importance of Material Things (pp. 9-12). Washington: Society for Historical Archaeology.

Doyle, P. J. (1981). Sociological Theory: Classical Founders and Contemporary Perspectives. New York: Wiley.

Durkheim, E. (1973). Moral Education: Studi in the Theory and Application of the Sociology of Education. New York: Free press.

Fraenkel, J. R. (1977). How to Teach about Values: An Analytic Approach. New Jersey: Prentice-Hall, Inc.

Fukuyama, F. (1995). Social Capital and The Global Economy. Foreign Affairs, 74(5), 89-103. http://dx.doi.org/10.5130/ccs.v5i3.3430

Green, A. W. (1972). Sociology: An Analysis of Life in Modern Society (5th ed). New York: Mc Graw-Hill Book Company

Horton, P. B., \& Hunt, C. L. (1980). Sociology (5th ed.). London: McGraw-Hill International Book Company.

Kroeber, A. L., \& Kluckhohn, C. (1952) .Culture: A Critical Review of Concepts and Definitions. Cambridge, MA: Peabody Museum.

Lamont, M., Beljean S., \& Clair, M. (2015). Cultural Knowledge and Social Inequality American Sociological Review, 80(1), 1-27. http://doi.org/10.1177/0003122414565814

Malinowski, B. (1944) . A Scientific Theory of Culture and Other Essays. London; Oxford; New York: Oxford University Press.

Schwartz, S. H., \& Bilsky, W. (1987). Toward a psychological structure of human values. Journal of Personality and Social Psychology, 53, 550-562. http://dx.doi.org/10.1037/0022-3514.58.5.878

Schwartz, S. H., \& Bilsky, W. (1990). Toward a psychological structure of human values: Extensions and cross-cultural replications. Journal of Personality and Social Psychology, 58(5), 878-891. http://dx.doi.org/10.1037/0022-3514.58.5.878

Sherif, M. (1935). A study of some social factors in perception. Archives of Psychology, 27(187).

Spradley, J. P. (1980). Participant observation. Orlando, FL: Harcourt Brace Jovanovich.

Tylor, E. B. (1871). The Origins of Culture and Religion in Primitive Culture. New York: Harper \& Brothers.

Wood, C., \& Leighton, D. (2010). Measuring Social Value: The gap between policy and practice. London: Demos.

Yin, R. K. (2003). Case Study Research—Design and Methods (3rd ed). London: Sage Publications.

Young, K. (1942). Sociology: A Study of Society and Culture. New York: American Book Company. 


\section{Copyrights}

Copyright for this article is retained by the author(s), with first publication rights granted to the journal.

This is an open-access article distributed under the terms and conditions of the Creative Commons Attribution license (http://creativecommons.org/licenses/by/3.0/). 